\title{
SISTEM INFORMASI PERMOHONAN PENGAJUAN BANTUAN BIBIT PERKEBUNAN PADA DINAS PERTANIAN DAN PANGAN KABUPATEN KUDUS
}

\author{
Syafira Indah Purnama Sari ${ }^{1}$, Fajar Nugraha ${ }^{2}$, Andy Prasetyo Utomo ${ }^{3}$ \\ ${ }^{123}$ Program Studi Sistem Informasi Fakultas Teknik Universitas Muria Kudus
}

\section{Article Info:}

Dikirim: 17 Desember 2020

Direvisi: 25 Desember 2020

Diterima: 30 Desember 2020

Tersedia Online: 31 Desember 2020

Penulis Korespondensi: Syafira Indah Purnama Sari

Universitas Muria Kudus, Kudus, Indonesia

Email:201753106@std.umk.ac.id
Abstrak: Salah satu program kegiatan yang dilaksankan oleh Dinas Pertanian dan Pangan Kabupaten Kudus adalah program kegiatan pengajuan bantuan bibit perkebunan yang ditujukan untuk kelompok tani yang diberikan oleh pemerintah. Bantuan bibit tersebut dapat dimanfaatkan untuk membantu petani dalam meningkatkan perekonomian petani. Dalam proses pengajuan bantuan bibit perkebunan, penyebaran informasi yang digunakan masih dilakukan secara konvensional dengan memberikan pengumuman di dinas, hal ini menjadi hambatan bagi petani untuk mencari informasi tentang bantuan bibit perkebunan yang ada di kudus, petani harus datang ke kantor Dinas Pertanian dan Pangan Kabupaten Kudus untuk mendapatkan informasi terkait dengan bantuan bibit yang tersedia. Dalam penelitian ini menggunakan metode pengembangan sistem Model Waterfall dan perancangannnnya menggunakan UML (Unified Modelling Languange). Hasil akhir pada penelitian ini adalah Sistem informasi pengajuan bantuan bibit perkebunan pada Dinas Pertanian dan Pangan Kabupaten Kudus.

Kata kunci: sistem informasi; pengajuan; bantuan; bibit perkebunan.

\begin{abstract}
One of the program of activities carried out by the Department of Agriculture and Food of Kudus Regency is the program for submitting plantation seed assistance aimed at farmer groups provided by the government. The seed assistance can be used to help farmers improve the farmer's economy. In the process of applying for plantation seed assistance, the dissemination of information used is still carried out conventionally by giving announcements at the office, this is an obstacle for farmers to seek information about plantation seed assistance in Kudus district, farmers must come to the city Agriculture and Food Service office Kudus to get information related to the available seeds. In this study using the Waterfall Model system development method and its design using UML (Unified Modeling Language). The final result of this research is an information system for applying for plantation seed assistance at the Department of Agriculture and Food of Kudus Regency.
\end{abstract}

Keywords: information systems; submission; assistance; plantation seeds. 


\section{PENDAHULUAN}

Dewasa ini peranan teknologi informasi untuk membantu dalam penyebarluasan informasi dan membantu dalam penyelesaian pekerjaan samakin dibutuhkan dalam sebuah organisasi. Kemajuan komputerisasi telah semakin mempengaruhi dan mendominasi dalam berbagai bidang kehidupan manusia, sehingga menimbulkan dampak positif bagi penerapan teknologi di lingkungan masyarakat. Sistem informasi pada suatu instansi pemerintah maupun swasta sangat dibutuhkan karena perkembangan teknologi yang sangat pesat menuntut suatu instansi untuk memperoleh serta menyebarluaskan informasi yang lebih cepat dan akurat. Sistem informasi yang mendukung kinerja suatu instansi akan terlaksana dengan baik dan dapat menangani berbagai pengelolahan data dengan menggunakan teknologi informasi.

Sektor pertanian merupakan salah satu sektor yang penting sebagai penggerak utama di bidang perekonomian oleh karenanya pengelolaan yang baik pada sector ini dapat membantu dalam meningkatkan kesejahteraan masyarakat [1]. Salah satu program yang dilaksanakan pada Dinas Pertanian dan Pangan Kabupaten Kudus adalah program kegiatan pemberian bantuan bibit perkebunan yang diberikan untuk kelompok tani di wilayah Kabupaten Kudus. Bibit ini diharapkan akan membantu petani dalam meningkatkan kualitas tanaman serta perekonomian petani. Dalam proses pengajuan bantuan bibit perkebunan, penyebaran informasi yang digunakan masih konvensional, hal ini menjadi hambatan bagi petani untuk mencari informasi tentang bantuan bibit perkebunan yang ada di kudus. Para petani harus datang ke kantor Dinas Pertanian dan Pangan Kabupaten Kudus untuk mencari informasi yang terkait dengan pemberian bantuan. Selain dengan datang secara langsung ke Dinas para petani juga dapat mendapatkan informasi dari pengumuman pada saat sosialisasi yang dilakukan oleh Dinas Pertanian dan Pangan Kabupaten Kudus. Syarat untuk mendapatkan bantuan bibit tersebut adalah sudah menjadi anggota kelompok tani yang memiliki lahan pertanian dan terdaftar di Dinas Pertanian dan Pangan Kabupaten Kudus yang dilakukan dengan mengajukan proposal bantuan.

Selain itu masih terdapat beberapa permasalahan lain yang menghambat proses operasional pada Dinas Pertanian dan Pangan Kabupaten Kudus, yaitu pengelolahan, penyimpanan, dan pembuatan laporan bibit pada Dinas Pertanian dan Pangan Kabupaten Kudus masih menggunakan semi komputer dalam pengelolahan data, proses penyimpanan data serta proses pelaporan saat ini diarsipkan dalam bentuk dokumen fisik, sehingga mengakibatkan kesulitan dalam pencarian informasi pengajuan bantuan bibit perkebunan kepada petani dan juga memungkinkan terjadinya kesalahan dalam pemprosesan data. Hal tersebut dirasa kurang efektif karena rentan terjadi kesalahan dalam pencatatan dan pengelolaan data pada proses pengajuan bantuan bibit yang dikelola oleh Dinas Pertanian dan Pangan Kabupaten Kudus.

Penelitian terkait dengan tema penelitian ini oleh Nelfira pada penelitiannya tentang Aplikasi Penyaluran Bibit Perkebunan Berbasis Web Pada Dinas Perkebunan Kabupaten Pasaman Barat" membahas pengembangan system informasi pada Dinas Perkebunan kabupaten Pasaman Barat. Dinas tersebut mempunyai program kegiatan penyaluran bibit perkebunan kepada kelompok tanimengenai penyaluran bibit dari sosialisasi yang dilakukan oleh Dinas Perkebunan dikota tersebut. Sistem yang berjalan saat ini masih terdapat kekurangan sehingga relative menyulitkan para petani dalam mengetahui keberadaan bibit terlebih masih kurangnya informasi tentang penyaluran bibit, proses pengolahan data penyaluran bibit di Dinas Perkebunan Kabupaten Pasaman Barat yang hal-hal tersebut rentan terdapat kesalahan serta menyebabkan keterlambatan dalam pelaporan penyaluran bibit dikarenakan proses pencarian data yang cenderung lama [2].

Penelitian yang berjudul Perancangan Sistem Informasidata Bibit Pada Balai Penyuluhan Pertanian Perikanan Dan Kehutanan (BP3K) Kec. Sitinjau Laut menjelaskan mengenai penerapan sistem informasi terkomputerisasi yang berbasis database yang membantu dalam pengelolaan serta pelaporan data pertanian khususnya dalam pendataan data bibit pertanian serta penyalurannya sehingga dapat meningkatkan pelayanan pada Balai Penyuluhan Pertanian Perikanan dan Kehutanan (BP3K) Kec. Sitinjau Laut [3].

Berdasarkan uraian diatas maka pada penelitian ini, penulis mengangkat judul "Sistem informasi permohonan pengajuan Bantuan Bibit Perkebunan pada Dinas Pertanian dan Pangan Kabupaten Kudus berbasis Web" yang diharapkan dapat membantu pengolahan serta penyimpanan data pengajuan.

\section{METODOLOGI PENELITIAN}

\subsection{Metode Pengembangan Sistem}

Proses pengembangan sistem merupakan bagian penting dari tahapan analisis. Pada artikel ini waterfall dipilih untuk menjadi metode pengembangan system. Waterfall model disebut juga alur hidup klasik atau sekuensial linier model [4]. Waterfall menyajikan siklus hidup aplikasi secara berurutan. Adapun tahapan pengembangan perangkat lunak yang dilakukan dengan mengacu pada waterfall model seperti berikut.

a) Analisa Kebutuhan

Yang dilakukan pada tahap ini adalah mengumpulkan kebutuhan yang ada secara detail untuk dapat merumuskan apa yang sebenarnya dibutuhkan user. Sehingga nantinya aplikasi yang dibangun sesuai apa yang diharapkan pengguna. Pada tahap ini sangat perlu untuk membuat dokumentasi spesifikasi software.

b) Desain Sistem

Yang dilakukan pada tahap ini menuangkan kebutuhan pengguna ke dalam rancangan dan desain sistem. Pada tahap ini desain system, database dan antar muka dibuat yang nantinya akan diteruskan ke programmer untuk dikonversi menjadi sebuah software aplikasi. Dokumentasi dalam bentuk diagram seperti FOD, DFD dan ERD sangat diperlukan pada tahap ini. 
c) Pengkodean

Yang dilakukan di tahapan ini adalah menuangkan hasil rancangan yang sudah dibuat pada tahap sebelumnya ke dalam sebuah aplikasi dengan cara menuliskan kode program dengan Bahasa pemrograman tertentu seperti PHP, ASP, JSP dan lain - lainnya.

d) Pengujian

Yang dilakukan pada tahapan ini adalah menguji atau melakukan test pada aplikasi yang sudah dibuat. Tes dilakukan baik dari sisi jalannya system atau sisi logic atau dari sisi kemudahan penggunaan. Hal ini dilakukan untuk mengurangi kesalahan yang bisa saja dilakukan user ketika menggunakan syitem yang dibangun.

e) Pemeliharaan (maintenance) / Pendukung (support)

Yang dilakukan pada tahapan ini adalah mengantisipasi apabila terjadi perubahan kebutuhan atau penambahan kebutuhan, sehingga memerlukan menyesuaian pada aplikasi yang telah dikembangkan.

\subsection{Perancangan Sistem}

Pada proses perancangan sistem ini, pemodelan perancangan sistem yang dipergunakan adalah Object-Oriented Design dengan menggunakan alat bantu desain unified modeling language (UML). Penerapan permodelan Object-Oriented Design yang digunakan pada perancangan sistem ini dapat membantu meminimalkan risiko kesalahan dalam proses perancangan sebuah sistem maupun perangkat lunak yang akan diimplementasikan [5].

\section{HASIL DAN PEMBAHASAN}

\subsection{Analisa Sistem Lama}

\subsubsection{FOD (Flow of Document)}

Flow Of Document atau FOD mengilustrasikan pergerakan dokumen fisik yang digunakan oleh sebuah sistem. Diagram ini memperlihatkan pergerakan dari dokumen fisik dari bagian ke bagian lain, dan apa saja dilakukan pada setiap dokumen pada setiap tahapan proses.

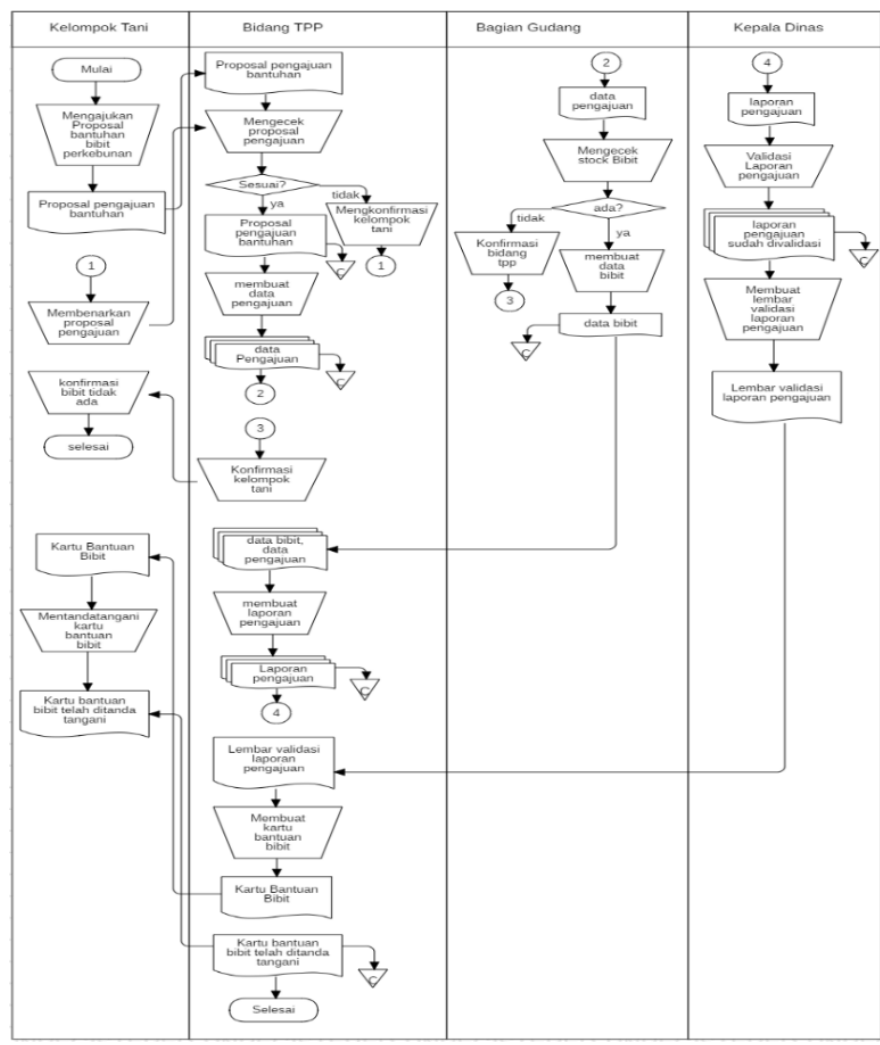

\section{Gambar 1. Flow of Document Sistem Pengajuan Bantuan Bibit Perkebunan}

Pada gambar 1 ditunjukkan alur sistem Pengajuan Bantuan Bibit Perkebunan, dimana ada 4 bagian yang berbagi peran yaitu kelompok tani, bagian gudang, administrasi, dan kepala dinas. Semua kegiatan masih dilakukan dengan cara konvensional memanfaatkan dokumen fisik. 


\subsection{Analisa dan Rancangan Sistem Baru}

Pendekatan sistem lebih menekankan pada suatu elemen ataupun komponen yang mendefiniskan sistem sebagai kumpulan dari beberapa elemen-elemen yang berinteraksi yang memiliki tujuan tertentu [6]. sistem informasi juga dapat mencakup sejumlah komponen yang dapat terdiri dari manusia, komputer, teknologi komunikasi, serta prosedur kerja yang diproses dari data menjadi suatu informasi yang dimaksudkan untuk mencapai suatu tujuan tertentu [7].

Dinas Pertanian dan Pangan Kabupaten Kudus mempunyai program kegiatan pengajuan bantuan bibit perkebunan kepada kelompok tani dari pemerintah, bibit ini akan membantu petani dalam meningkatkan perekonomian petani. Dalam proses pengajuan bantuan bibit perkebunan, penyebaran informasi yang digunakan masih manual, hal ini menjadi hambatan bagi petani untuk mencari informasi tentang bantuan bibit perkebunan yang ada di kudus, petani harus datang ke kantor Dinas Pertanian dan Pangan Kabupaten Kudus untuk mencari informasi. Petani yang ingin mengajukan bantuan bibit perkebunan mendapatkan informasi dari sosialisasi yang dilakukan oleh Dinas Pertanian dan Pangan Kabupaten Kudus dengan syarat sudah menjadi anggota kelompok tani yang terdaftar di Dinas Pertanian dan Pangan Kabupaten Kudus, mengajukan proposal dan memiliki lahan pertanian. Dinas Pertanian dan Pangan Kabupaten Kudus memberikan bibit kepada kelompok tani antara lain bibit kopi, bibit cenggeh, bibit jambu air, bibit durian, dan bibit rambutan.

Selain itu, masih ada masalah lain yang menghambat proses operasional pada Dinas Pertanian dan Pangan Kabupaten Kudus. Yaitu pengelolahan, penyimpanan, dan pembuatan laporan bibit pada Dinas Pertanian dan Pangan Kabupaten Kudus masih menggunakan semi komputer dalam pengelolahan data, proses penyimpanan data serta pembuatan laporan saat ini diarsipkan dalam bentuk file, sehingga mengakibatkan kesulitan dalam pencarian informasi pengajuan bantuan bibit perkebunan kepada petani dan juga memungkinkan terjadinya kesalahan dalam pemprosesan data. Hal ini dirasa tidak efektif, karena dapat menyebabkan terjadi kesalahan dalam pencatatan dan pengelolahan pengajuan bantuan bibit pertanian yang dilakukan.

\subsubsection{Bussiness Use Case}

Bisnis use case merupakan gambaran permodelan pada proses bisnis suatu organisasi. Bisnis use case juga dapat menjelaskan mengenai aktivitas bisnis utama yang dilaksanakan pada sebuah proses bisnis organisasi [8].

Business Use Case dari proses bisnis pengajuan bantuan bibit perkebunan dapat dilihat pada gambar dibawah ini. Dalam business use case memiliki 4 aktor, yaitu kelompok tani, bagian gudang, admin (bidang tpp) dan kepala dinas. Dalam bisnis use case menunjukkan gambaran hubungan antara proses yang satu dengan proses yang lainnya. Gambar 2 menggambarkan tentang bisnis use case diagram pengajuan bantuan bibit perkebunan.

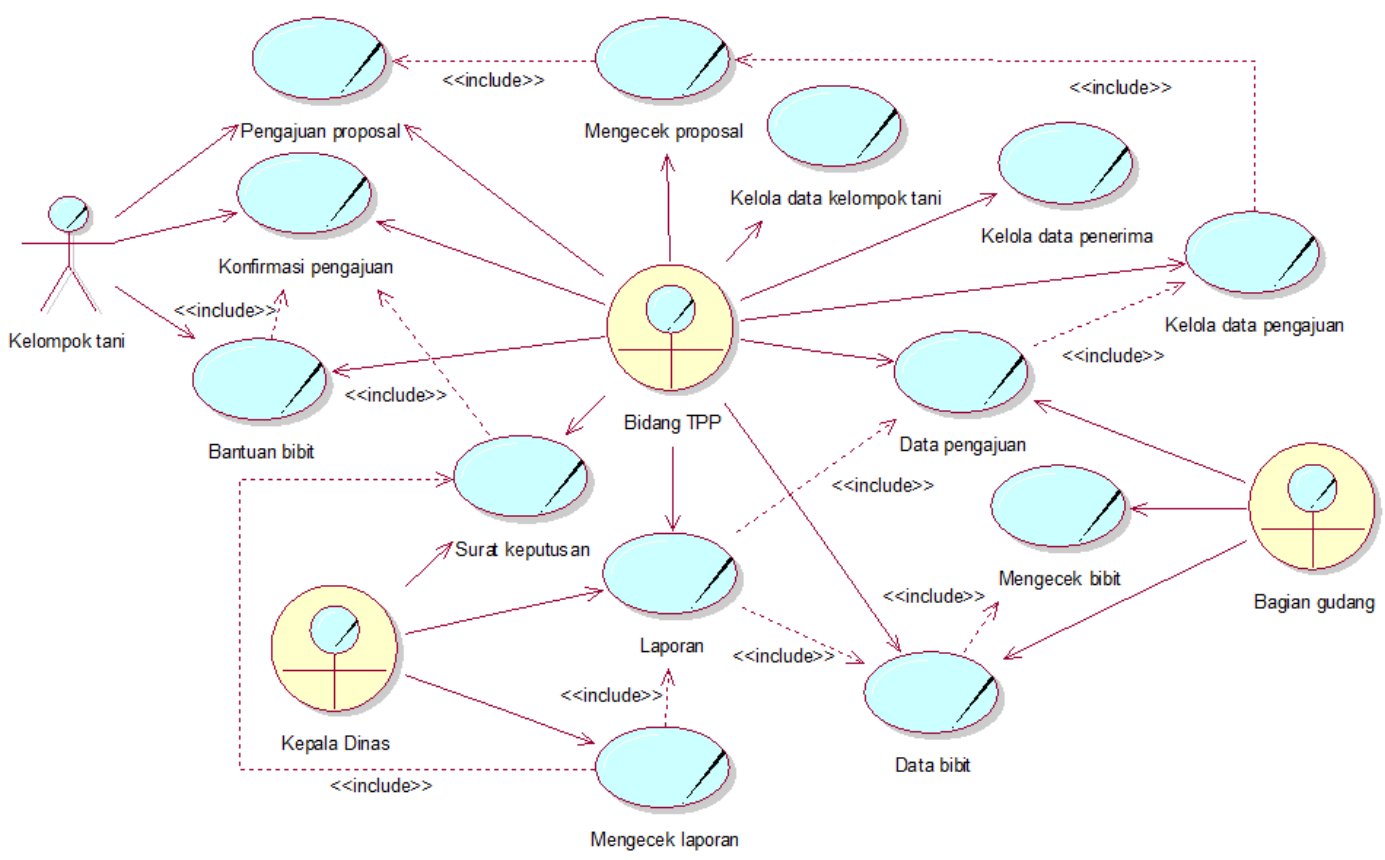

Gambar 2. Bisnis Use Case Diagram Pengajuan Bantuan Bibit Perkebunan

\subsubsection{System Use Case}

Sistem Use Case dari sistem informasi permohonan pengajuan bantuan bibit perkebunan pada Dinas Pertanian dan Pangan Kabupaten Kudus Berbasis Web dapat dilihat pada gambar dibawah ini. Dalam use case diagram memiliki 4 aktor yaitu admin, kelompok tani, bagian gudang dan kepala dinas. Gambar 3 menggambarkan tentang use case diagram pengajuan bantuan bibit perkebunan. 


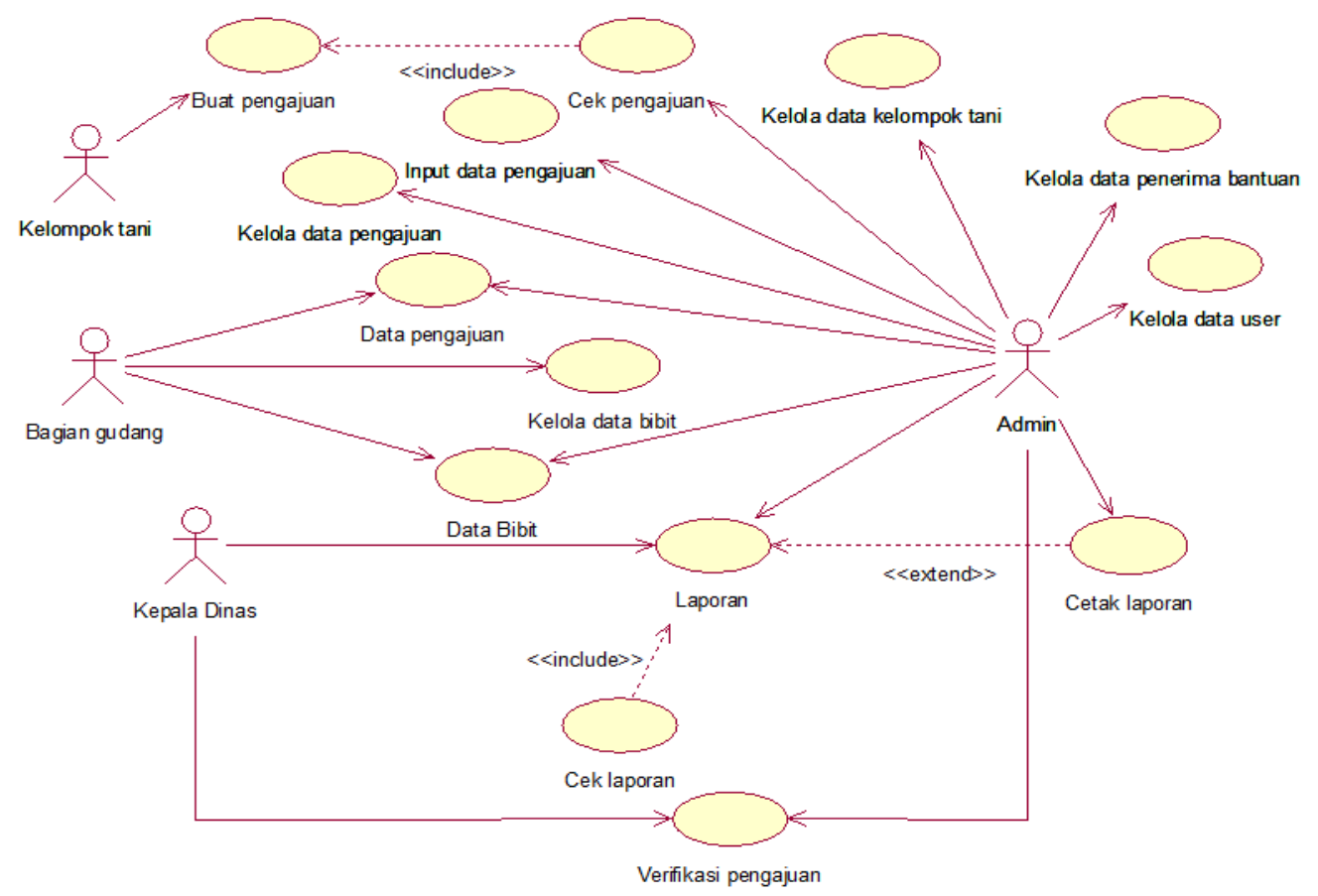

Gambar 3. Sistem Use Case Diagram Pengajuan Bantuan Bibit Perkebunan

\subsubsection{Class Diagram}

Class Diagram dari sistem informasi permohonan pengajuan bantuan bibit perkebunan pada Dinas Pertanian dan Pangan Kabupaten Kudus berbasis web. Gambar 4 menggambarkan tentang class diagram dalam pengajuan bantuan bibit perkebunan.

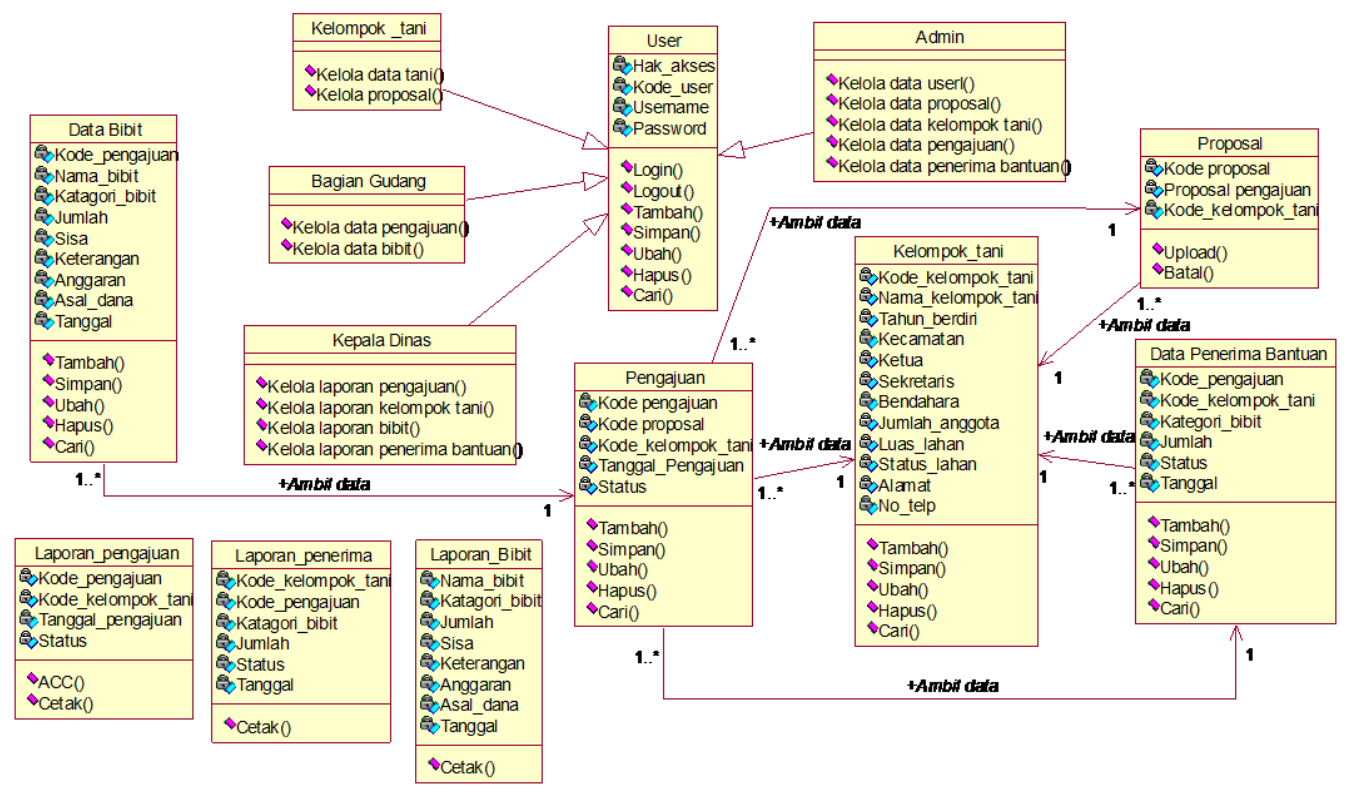

\section{Gambar 4. Class Diagram Pengajuan Bantuan Bibit Perkebunan}

\subsubsection{Entity Relattionship Diagram}

ERD dari sistem informasi permohonan pengajuan bantuan bibit perkebunan pada Dinas Pertanian dan Pangan Kabupaten Kudus berbasis web dapat dilihat pada gambar dibawah ini. Gambar 5 menjelaskan tentang ERD (Entity Relationship Diagram). 


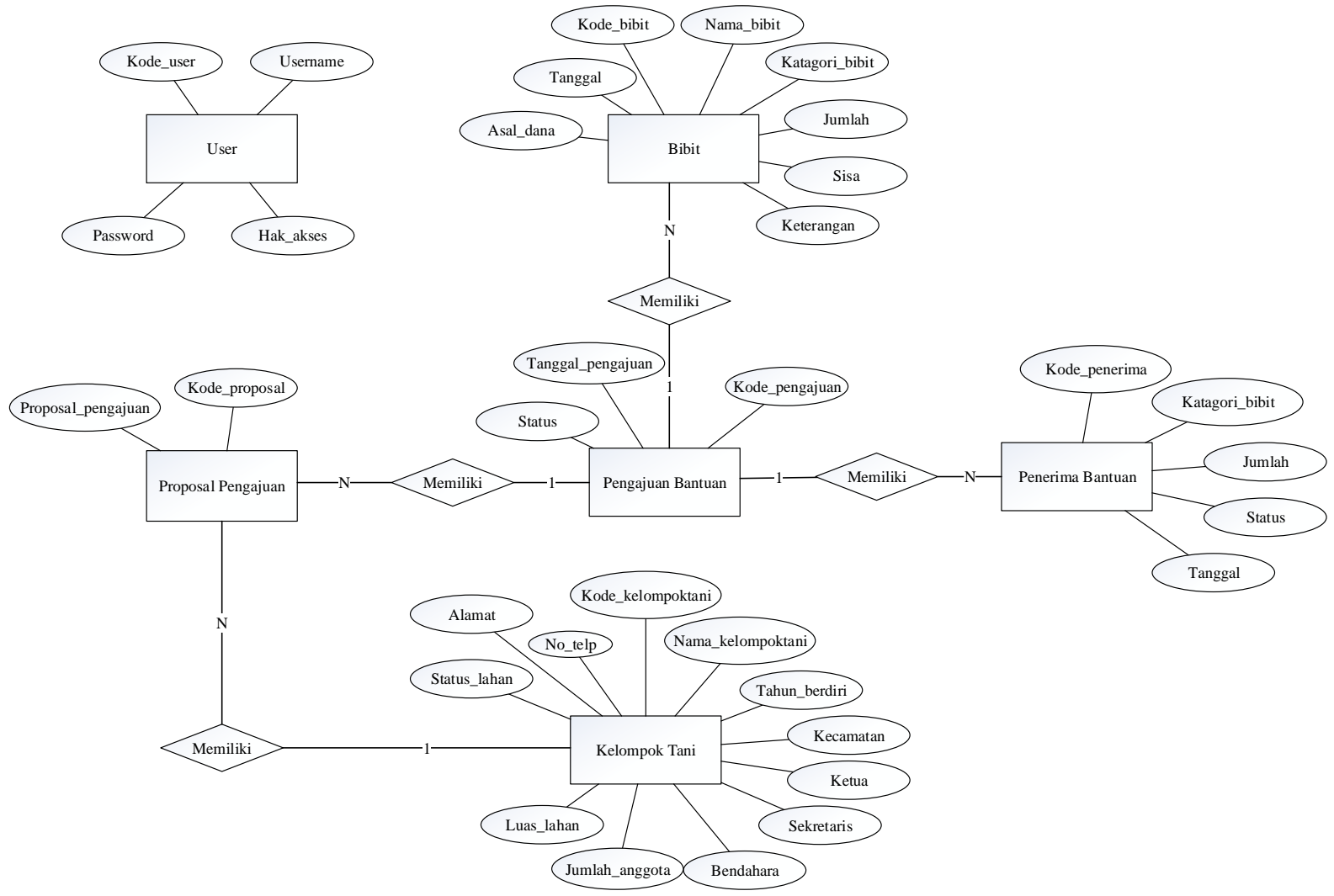

Gambar 5. ERD (Entity Relationship Diagram)

\subsubsection{Relasi Tabel}

Relasi Tabel dari sistem informasi permohonan pengajuan bantuan bibit perkebunan pada Dinas Pertanian dan Pangan Kabupaten Kudus berbasis web menggambarkan tentang hubungan antara beberapa table yang saling berelasi satu dengan yang lainnya. Gambar 6 menunjukkan relasi table antara beberapa tabel.

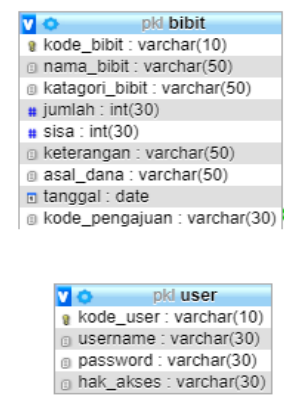

\subsubsection{Implementasi}

a. Halaman Utama Admin

Halaman utama bagian admin ini merupakan tampilan utama yang muncul setelah admin melakukan login. Pada Halaman utama bagian admin dapat digunakan untuk mengelola data user, data kelompok tani, data pengajuan dan data penerima bantuan. Gambar 7 menunjukkan halaman utama admin dalam aplikasi sistem pengajuan bantuan bibit perkebunan. 


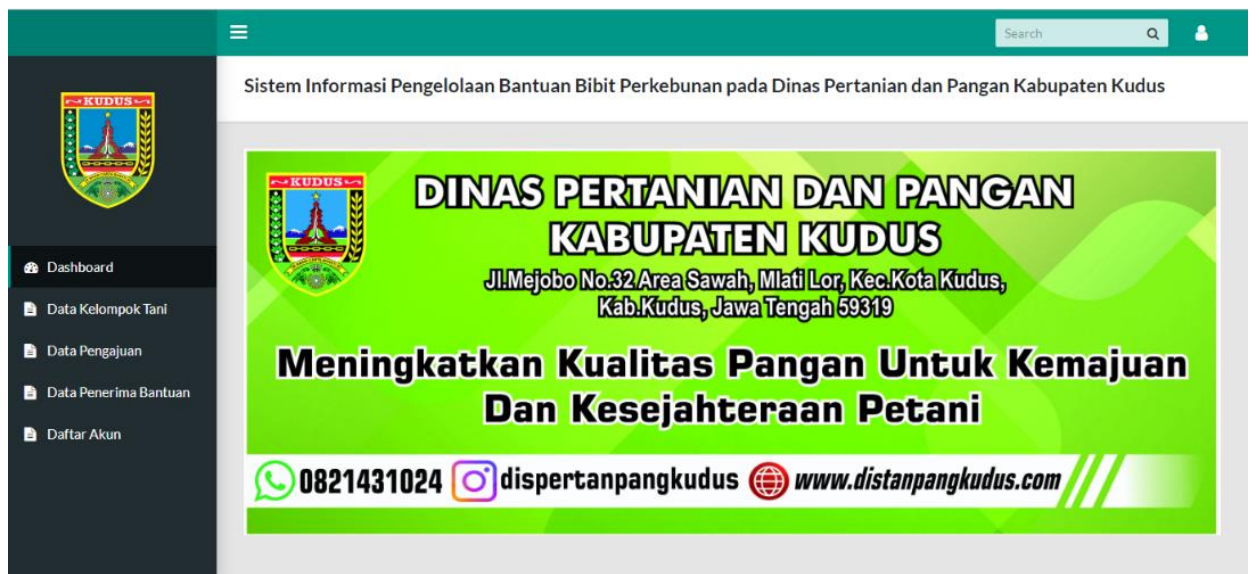

\section{Gambar 7. Halaman Utama Admin}

b. Halaman Utama Kelompok Tani

Halaman utama bagian Kelompok Tani ini merupakan tampilan utama yang muncul setelah Kelompok Tani melakukan login. Pada halaman utama bagian kelompok tani dapat digunakan untuk mengupload proposal pengajuan bantuan dan mengelola data kelompok tani. Gambar 8 menggambarkan tentang halaman utama kelompok tani.
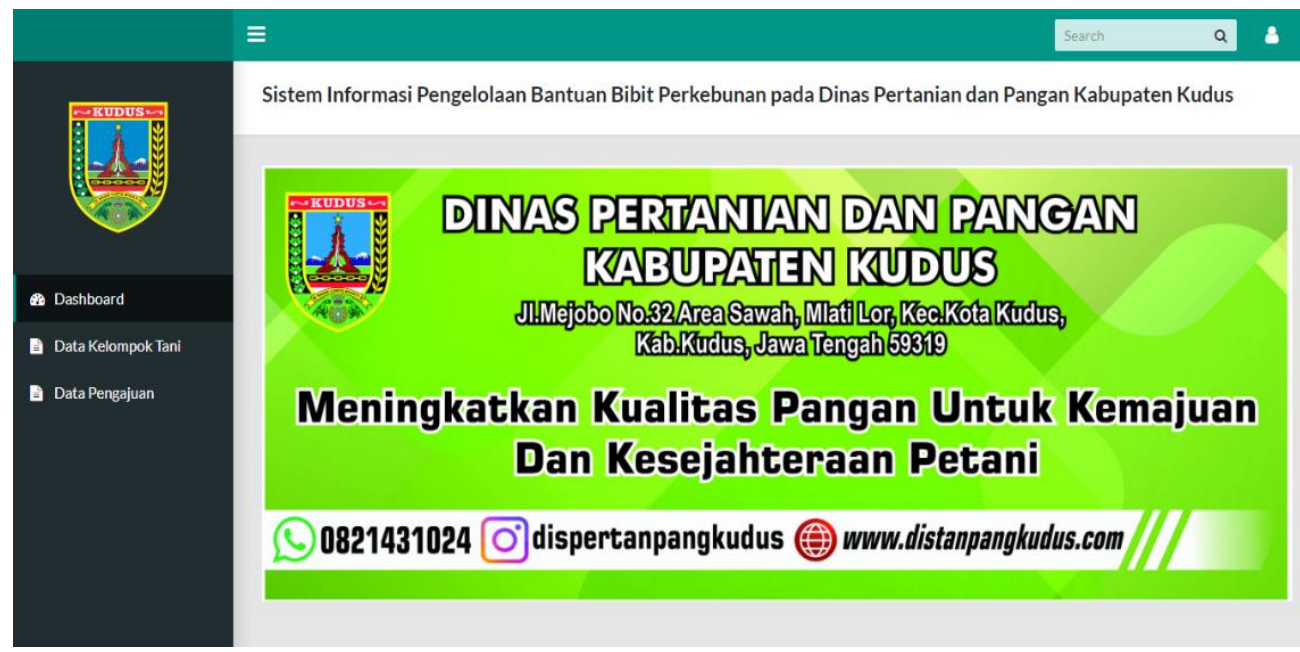

\section{Gambar 8. Halaman Utama Kelompok Tani}

c. Halaman Input Proposal Permohonan Pengajuan

Tampilan form input Proposal Pengajuan pada hak akses kelompok tani digunakan untuk mengupload proposal permohonan pengajuan bantuan bibit perkebunan yang dapat dilakukan oleh kelompok tani. Gambar 8 menunjukkan tentang halaman input proposal pengajuan bantuan bibit perkebunan.

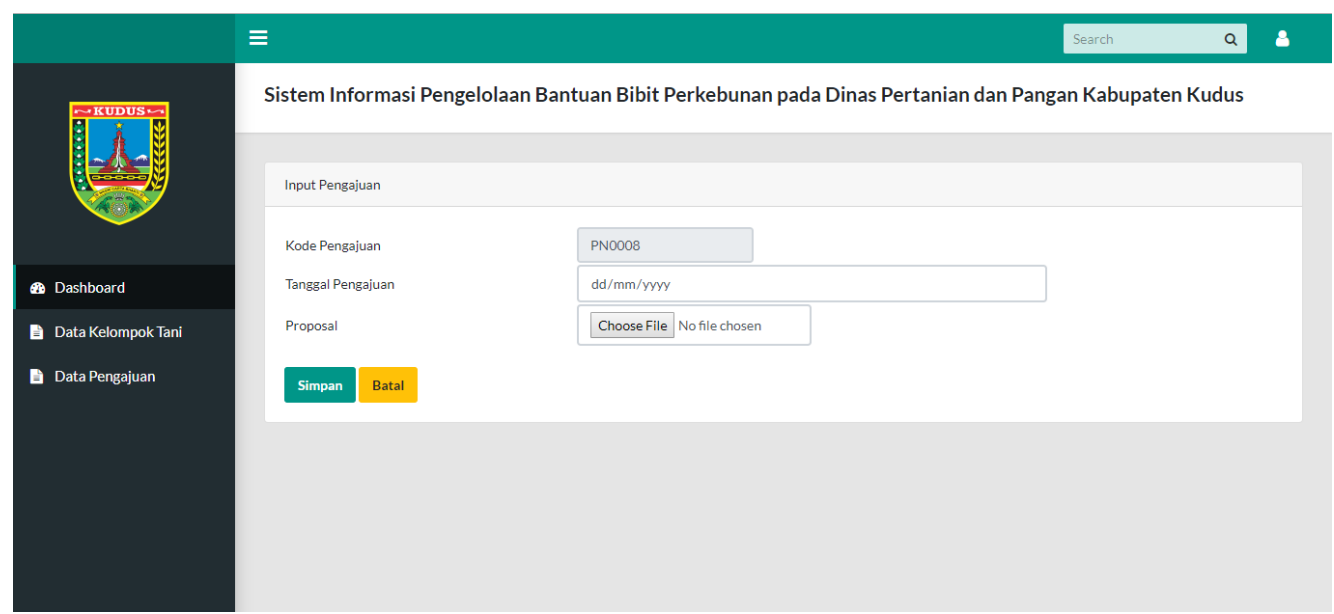

Gambar 9. Halaman Input Proposal Pengajuan 


\section{KESIMPULAN}

Berdasarkan hasil analisis dan perancangan, implementasi, serta pembahasan yang telah diuraikan di setiap bab-bab diatas dapat diambil beberapa kesimpulan sebagai berikut:

1) Sistem informasi permohonan pengajuan Bantuan Bibit Perkebunan pada Dinas Pertanian dan Pangan Kabupaten Kudus ini menggunakan metode pengembangan sistem Waterfall sedangkan metode dalam perancangan sistem yang digunakan adalah object-oriented design (OOD) dengan menggunakan tool perancangan desain unified modeling language (UML).

2) Sistem ini dibangun untuk mengelola data pengajuan bantuan yang meliputi data kelompok tani, data proposal pengajuan bantuan, data pengajuan bantuan, data penerima bantuan, dan data bibit.

3) Sistem ini menghasilkan informasi yang sangat dibutuhkan oleh kelompok tani dan kepala dinas yaitu berupa informasi pengajuan bantuan bibit perkebunan dan laporan kelompok tani, laporan pengajuan bantuan, laporan penerima bantuan, dan laporan data bibit.

4) Sistem informasi permohonan pengajuan bantuan bibit perkebunan pada Dinas Pertanian dan Pangan Kabupaten Kudus ini dibangun dengan menggunakan bahasa pemrogaman PHP dan dengan database MySQL.

\section{DAFTAR PUSTAKA}

[1] N. Aprini, "Perancangan sistem Informasi Pemasaran hasil pertanian berbasis Webdikota Pagar Alam," Jurnal Informatika Lembah Denpo, vol. 7, no. 2, pp. 13-24, 2019.

[2] S. N. P. Nelfira, "Aplikasi Peyaluran Bibit Perkebunan Berbasis Web pada Dinas Perkebubab Kabupaten Pasaman Barat," Jurnal Informatika, vol. 6, no. 2, pp. 322-328, 2019.

[3] I. S. Heru Saputra, "Perancangan Sistem Informasi data Bibit Pada Balai Penyuluhan Pertanian Perikanan Dan Kehutanan (BP3K) Kec. Sitinjau Laut," Journal Of Information System And Informatics Engineering, vol. 1, no. 2, pp. 77-84, 2017.

[4] R. Pressman, Rekayasa Perangkat Lunak: Pendekatan Praktisi Buku I, Yogyakarta: Andi, 2015.

[5] G. e. a. Booch, Object Oriented Analysis And Design With Applications, Pearson, 2019.

[6] Jogiyanto, Analisis dan Desain Sistem Informasi, Yogyakarta: Andi, 2005.

[7] A. Kadir, Pengenalan Sistem Informasi, Yogyakarta: Andi, 2003.

[8] Sholiq, Permodelan Sistem Informasi Berorientasi Obyek dengan UML, Yogyakarta: Graha Ilmu, 2006. 